\title{
Terrorism as a Public Emergency: The Imperative for Human Rights Compliant Counter Terrorism Strategies in Nigeria
}

\author{
Kolawole, Adeejat Kubra A. ${ }^{*} \quad$ Udombana, N. J. ${ }^{2}$ \\ 1.Doctoral candidate, College of Law and Security Studies, Babcock University, Ilishan Remo \\ 2.Professor, Department of Jurisprudence and International Law, College of Law and Security Studies, Babcock \\ University, Ilishan Remo
}

\begin{abstract}
Terrorism clearly has a very real and direct impact on human rights, with devastating consequences for the enjoyment of the right to life, liberty and physical integrity of victims. Globally, terrorism is now viewed as a public emergency and post $9 / 11$ counter terrorism strategies have combated terrorism as one would a public emergency. Nigeria desired the protection of its citizens from the violations of their human rights hence the enactment of certain counter terrorism strategies. This paper investigated the extent to which counter terrorism strategies enacted and implemented by the Nigerian state resonate with international best practices for protection of human rights while confronting a public emergency. The paper found that Nigeria seemed to have designed her counter terrorism strategies to counter the very lofty ideals of human rights which she is internationally obligated to protect. The study concluded that internationally accepted norms for derogation under international human rights law in the face of public emergency has been exceeded by the Nigerian state through draconian strategies such as arbitrary arrest, unlawful detention, extra judicial killings, inhumane treatment and torture. The paper recommended both normative and institutional reforms such that the Nigerian counter-terrorism legal framework becomes anchored on internationally accepted norms of non-derogation of core rights to life, personal dignity, freedom from torture, cruel and inhumane treatment even in times of public emergency.
\end{abstract}

Keywords: Counter terrorism strategies, Human Rights, Public Emergency, Terrorism.

DOI: $10.7176 / \mathrm{JLPG} / 117-06$

Publication date: January $31^{\text {st }} 2022$

\section{Introduction}

This works seeks to determine the extent to which the Nigerian Counter terrorism strategies (CTS) resonate with international best practices while countering terrorism as a public emergency. Within the context of this study, international best practices will be distilled from international human rights norms enacted by customary international laws, human rights Conventions, guidelines, measures and practices established by both the United Nations (UN) Charter based and Treaty based monitoring institutions. As well, we shall refer to jurisprudence issuing from different jurisdictions on similar human rights norms and practices.

Together with this introduction which is the first part, this paper is presented in five parts. The second section discusses the notion of public emergency under international human rights law. The third segment analyses the requirements as set by international law as signalling public emergency and the standards laid down at international human rights law for protection of human rights. The fourth sector presents a compelling statistics on why terrorism qualifies as a public emergency in Nigeria and also measures the Counter-terrorism strategies as enacted under the Terrorism Prevention Act, (TPA) 2011 as amended in 2013 and institutionalised by National Counter-terrorism Strategy (NACTEST) vis a- vis the standards set at international law. Under that sector, a portion is devoted to a review of allegations of violations of citizen's non derogable human rights by state agents. The fifth component presents our concluding comments, observations and recommendations.

\section{The Notion of Public Emergency Under International Human Rights Law}

International human rights law realises that certain circumstances may arise creating serious crisis which threatens the very foundation or life of a state and which may make it imperative for such a state to protect itself by derogation from the guarantees of rights to its citizen. Such circumstances would call for declaration of state of emergency.

At the international level, the principal provision on permissible limits of derogations of human rights during state of emergency by international convention is found in Article 4 (1) of the ICCPR which provides thus:

In the time of public emergency which threatens the life of the nation and the existence of which is officially proclaimed, the States Parties to the present Covenant may take measures derogating from their obligations under the present Covenant to the extent strictly required by the exigencies of the situation, provided that such measures are not inconsistent with their other obligations under international law and do not involve discrimination solely 
on the ground of race, colour, sex, language, religion or social origin.

Similar provisions can be found in other international conventions. ${ }^{1}$ For example, at the regional level, Article 27(1) of the American Convention on Human Rights reads as follows:

"In time of war, public danger, or other emergency that threatens the independence or security of a State Party, it may take measures derogating from its obligations under the present Convention to the extent and for the period of time strictly required by the exigencies of the situation, provided that such measures are not inconsistent with its other obligations under international law and do not involve discrimination on the ground of race, color, sex, language, religion, or social origin."

Again, Article 15(1) of the European Convention on Human Rights stipulates that:

"In time of war or other public emergency threatening the life of the nation any High Contracting Party may take measures derogating from its obligations under this Convention to the extent strictly required by the exigencies of the situation, provided that such measures are not inconsistent with its other obligations under international law.'

Paradoxically, the African Charter on Human and Peoples' Rights contains no derogation provision. In the view of the African Commission on Human and Peoples' Rights, this means that the African Charter "does not allow for states parties to derogate from their treaty obligations during emergency situations". ${ }^{3}$ In other words, even a civil war cannot "be used as an excuse by the state (for) violating or permitting violations of rights in the African Charter".

In the exercise of its mandate to enforce the ICCPR, the Human Rights Committee adopted the UN HRC General Comment (GC) No. 29 adopted at its $1950^{\text {th }}$ session on 24 July 2001 (hereinafter UNHRCGC 29). The UNHRCGC 29 by its paragraph 2 declared that before a State moves to invoke article 4, two fundamental conditions must be met: the situation must amount to a public emergency which threatens the life of the nation, and the State party must have officially proclaimed a state of emergency. The power to declare a state of emergency must be made by the state in accordance with the rule of law and the state's constitution in order to ensure that the declaration complies with the rule of law and the grundnorm regulating same in the state. ${ }^{2}$

Furthermore to forestall an arbitrary or frequent declaration of states of emergency we must point out that paragraph 3 of the UNHRCGC 29 cautions that not every disturbance or catastrophe is a public emergency. ${ }^{3}$ In order to act as safeguards for the protection of the human rights of the citizens, the judiciary of the concerned state must be given the greatest possible extent of power in states of emergency.

The case of Greece $v$. the $U K^{4}$ is perhaps the oldest case in which a regional adjudicatory body/court has had to decide on what constitute a public emergency. The European Commission on Human Rights was faced with the task of interpreting a similar provision as Article 4 of the ICCPR which is Article 15 of the European Convention on Human Rights. The Commission and subsequently the Court developed the following criteria for scrutiny of application by state for derogation of human rights in times of public emergency:

1. The emergency must be actual or imminent.

2. Its effects must involve the whole nation

3. The continuance of organised life in the community must be threatened

4. The crisis or danger must be exceptional, in that the normal measures or restrictions, permitted by the Convention for the maintenance of public safety, health and order, are plainly inadequate.

The ECtHR in the case of Lawless v. Ireland, ${ }^{5}$ defined a "public emergency" as:

A "danger or crisis" that is

i. $\quad$ Present or imminent,

ii. Exceptional,

iii. Concerns the entire population,

iv. Constitutes a "threat to the organized life of the community."

\section{The UN Conventions and Standards for Declaration of State of Emergency as Counter- Terrorism Measure}

The proclamation of a state of emergency by a nation is regulated by international law and international human rights law and its guiding principles because it signals the curtailment of certain civil liberties which. To safeguard and prevent excesses on the parts of state agents; international law puts in place certain minimum

${ }^{1}$ See for example, American Convention on Human Rights (art. 27) and the European Convention on Human Rights (art. 15).

${ }^{2}$ See Human Rights Committee, General Comment 29, States of Emergency (article 4), U.N. Doc. CCPR/C/21/Rev.1/Add.11 (2001) para. 2, $<$ http://hrlibrary.umn.edu/gencomm/hrc29.html $>$ accessed 2 March 2021.

${ }^{3}$ See Human Rights Committee, General Comment 29, States of Emergency (article 4), U.N. Doc. CCPR/C/21/Rev.1/Add.11 (2001), para. $3,<$ http:/hrlibrary.umn.edu/gencomm/hrc29.html $>$ accessed 2 March 2021.

${ }^{4}$ Greece v. UK, Application No157/1954-58. <https://www.coe.int/t/dghl/cooperation/lisbonnetwork/themis/echr/paper2_en.asp $>$ accessed 2 March 2021.

${ }^{5}$ Lawless v. Ireland, (Lawless Court ) 3 Eur.Ct. H.R. (ser. A) (1961) (No. 3) (Court), at 56

${ }^{6}$ Lawless, Ibid 
standards by which the conduct of a state in times of emergency may be monitored, restricted or sanctioned. These measures as provided under Article 4 (1) - (3) of the International Covenant on Civil and Political Rights (ICCPR) are reviewed hereunder.

3.1. The Normative Standards: Article 4 of the ICCPR: Setting the Standards for State of Emergency under International Human Rights Law

The ICCPR fails to describe what qualifies as "public emergency" or give an index of circumstances which would "threaten the life of the nation" to qualify as public emergency which raises the possibility of arbitrary invocation of Art 4(1) by states. Nonetheless the UN Human Rights Committee (HRC) of the United Nations which is charged with the task of implementing the ICCPR has furnished some comments ${ }^{1}$ interpretations and decisions on this Article. This shall be the basis for distilling the best practices which has been accepted and acted upon by states as compliance with the precepts of article 4 (1) of the ICCPR

The GC29 $29^{2}$ sets the standard norms and procedure which every state must comply with before it can invoke article 4 (1) of the ICCPR namely:

\section{a. Existence of a public emergency which threatens the life of that state}

The GC29 notes that while not every public disturbance qualifies as a public emergency, situations such as armed conflicts be it international or non-international will however be deemed as public emergencies. ${ }^{3}$ Thus the situation must be so serious as to constitute a threat to the life of the state. By several communications the Committee had considered this situation in and decided that not every natural catastrophes, mass demonstration or industrial action, strike or riots constitutes a life threatening situation. For example the Committee struck down the constitutional provisions of the United Republic of Tanzania declaring a state of emergency on the grounds that they are too broad and that the extraordinary powers of the President in an emergency are too sweeping". 4

A similar provision contained in the European Convention on Human Rights (ECHR), has also been interpreted by the European Court of Human Rights (ECtHR) in the case of Lawless v. Republic of Ireland where the European Court on Human Rights held that "a public emergency ....is an exceptional and imminent crisis affecting the general public as opposed to particular groups which threatens the organised life of the community". Furthermore in the Greek Case the ECtHR formulated four criteria by which a nation may determine if a public emergency has arisen namely that the emergency must be actual or imminent, must involve the nation as a whole and not a segment of it, the emergency must threaten the organised life of the community and it must be exceptional in such a way that the measures and restrictions permitted under the treaty are inadequate to deal with it.

b. The proclamation of a state of emergency. ${ }^{5}$

The principle of proclamation is essential for the purpose of legality of the action as the GC29 notes that the proclamation of a state of emergency is dependent on whether or not the constitutional provisions of the particular state allows for same.

\section{c. The principle of Non Derogability of certain rights}

The ideal of non derogability of certain rights finds basis on both the concept of the customary international law principle of jus cogens and certain international Conventions.

\section{i. The Principles of Jus Cogens and Non Derogable rights}

Universally accepted as a customary international norm, jus cogens connotes rights which can never be derogated from by any state at any time not even it times of public emergencies, state of war or such human security threatening situations. Whenever the exercise of state sovereignty will operate to incur loss of respect and promotion of human rights, international law steps in to prevent such decision by invoking the letters of the jus cogens. Jus cogens is thus a legal method to override state prerogative to decide when to respect or dishonour human rights such.

The principle of Jus Cogens has its roots in the tenets of natural law postulation of universal values. The first legal restatement of the principle of jus cogens can be found in the provisions of article 53 of the Vienna Convention on the Law of Treaties, $(\mathrm{VCLT})^{6}$ which defines the jus cogens as follows:

\footnotetext{
${ }^{1}$ The UNHRC General comment 5 of 1981 has since been replaced by the general comment 29 of 2001

${ }^{2}$ See UN Human Rights Committee (HRC), CCPR General Comment No. 29: Article 4: Derogations during a State of Emergency, 31 August 2001, CCPR/C/21/Rev.1/Add.11, available at: https://www.refworld.org/docid/453883fd1f.html [accessed 15 January 2020] hereinafter 'UNHRC GC29 of 2001'

${ }^{3} \mathrm{UNHRC}$ GC29 of 2001, paragraph 3

${ }^{4}$ UN doc. GAOR, A/48/40 (vol. I), p. 43, para. 184, and p. 44, para. 188; see C. Salgar de Montejo v. Colombia (Views adopted on 24 March 1982), UN doc. GAOR, A/37/40, Cited in 'Administration of Justice during States of Emergency' $<$ https://www.ohchr.org/Documents/Publications/training9chapter16en.pdf >accessed 15 January 2020 ..

${ }^{5}$ UNHRC GC29 of 2001, paragraph 2.

${ }^{6}$ Vienna Convention on the Law of Treaties UNTS 18232. <https://treaties.un.org/doc/publication/unts/volume\%201155/volume-1155-i18232-english.pdf $>$ accessed on 20 November 2020.
} 
For the purposes of the present Convention, a peremptory norm of general international law is a norm accepted and recognized by the international community of States as a whole as a norm from which no derogation is permitted and which can be modified only by a subsequent norm of general international law having the same character".

The United Nations International Law Commission describes jus cogens as A peremptory norm of general international law (jus cogens) is a norm accepted and recognized by the international community of States as a whole as a norm from which no derogation is permitted and which can be modified only by a subsequent norm of general international law having the same character. ${ }^{1}$

Some of the accepted peremptory rule of general international law is provided in a non-exhaustive list include: (a) the prohibition of aggression; (b) The prohibition of genocide; (c) The prohibition of crimes against humanity; (d) The basic rules of international humanitarian law; (e) The prohibition of racial discrimination and apartheid; (f) The prohibition of slavery; (g) The prohibition of torture; and (h) The right of self-determination. ${ }^{2}$

Jurisprudence from international, regional and domestic courts and human rights commissions indicate the acceptance of the jus cogens as compelling laws from which no state is immune from. In Michael Domingues v. United States ${ }^{3}$ where that Commission linked peremptory norms of general international law (jus cogens) to "public morality" and, more importantly, stated that they "derive their status from fundamental values held by the international community", noting that violations of jus cogens "shock the conscience of humankind."

ii. International Conventions and Non-Derogable Rights

The notion of non-derogability of the peremptory norms even in the face of public emergency is a feature of numerous international conventions. First is the International Covenant on Civil and Political Rights (ICCPR). Article 4(2) of the CCPR provides that no derogation are permitted from articles 6, 7, 8 (paragraphs 1 and 2), 11, 15,16 and 18. Thus the right to life $^{4}$, right to humane treatment ${ }^{5}$, freedom from criminal ex post facto laws ${ }^{6}$, freedom from slavery ${ }^{7}$, from discrimination on the basis of race, colour, sex, language, religion or social origin ${ }^{8}$, freedom from imprisonment for civil debt ${ }^{9}$, right to legal person-hood ${ }^{10}$ and freedom of thought, religion and conscience. ${ }^{11}$

Second, the Convention Against Torture and Other Cruel, Inhuman or Degrading Treatment or Punishment (CAT) provides that the right to freedom from torture and other cruel, inhuman or degrading treatment or punishment $^{12}$ is non-derogable. Third, the Convention on the Prevention and Punishment of the Crime of Genocide ${ }^{13}$, prohibits genocide even times of public emergency. ${ }^{14}$ Fourth, the Geneva Convention No. IV: Geneva Convention Relative to the Protection of Civilian Persons in Time of War. ${ }^{15}$ Fifth is the Rome Statute of the International Criminal Court (Rome Statute) ${ }^{16}$ prohibits war crimes ${ }^{17}$ and crimes against humanity even in

\footnotetext{
UN-ILC $/ 10$ GE.19-13883 Chapter V: Peremptory norms of general international law (jus cogens), 141 $<$ https://legal.un.org/ilc/reports/2019/english/chp5.pdf> accessed 3 December 2020.

2 See UN-ILC A/74/10 GE.19-13883, 147 Annex I.

${ }^{3}$ Case 12.285, Inter-American Commission on Human Rights, Report No. 62/02 of 22 October 2002, para. 49). See also European Court of Human Rights in Al-Adsani v. the United Kingdom, Application no. 35763/97, Judgment of 21 November 2001, Kaunda and Others v. President of the Republic of South Africa \& Others (Society for the Abolition of the Death Penalty in South Africa intervening as Amicus Curiae) 2005 (4) SA 235 (CC); Mann v. Republic of Equatorial Guinea, Case No. 507/07, Judgment of 23 January 2008, High Court of Zimbabwe, [2008] ZWHHC 1.

${ }^{4}$ ICCPR, Art. 6.

${ }^{5}$ ICCPR, Art. 7.

${ }^{6}$ ICCPR, Art. 1.5

${ }^{7}$ ICCPR. Art. 8.

${ }^{8} \mathrm{ICCPR}$, Art. 4, Art. 16

${ }^{9} \mathrm{ICCPR}$, Art. 11

${ }^{10} \mathrm{ICCPR}$ Art. 16

${ }^{11}$ ICCPR, Art. 18; See also para 7 of the UN Human Rights Committee (HRC), CCPR General Comment No. 29: Article 4: Derogations during a State of Emergency, 31 August 2001, CCPR/C/21/Rev.1/Add.11,<https://www.refworld.org/docid/453883fd1f.html >accessed 15 January 2020]

${ }^{12}$ CAT (Art. 2(2))

${ }^{13}$ Convention on the Prevention and Punishment of the Crime of Genocide

Approved and proposed for signature and ratification or accession by General Assembly resolution 260 A (III) of 9 December 1948 Entry into force: 12 January 1951, in accordance with article XIII https://www.ohchr.org/en/professionalinterest/pages/crimeofgenocide.aspx > accessed $28^{\mathrm{t}}$ November 2020.

${ }^{14}$ Genocide Convention, Art 1.

${ }^{15}$ Geneva Convention Relative to the Protection of Civilian Persons in Time of War, Aug. 12, 1949, 6 U.S.T. 3516, 75 U.N.T.S. 287; $<$ http://www.un.org/en/genocideprevention/documents/atrocity-crimes/Doc.33 GC-IV-EN.pdf $>$ accessed $28^{\text {th }}$ November 2018.

16 Rome Statute of the International Criminal Court $\overline{\mathrm{h}} \mathrm{htps} / / \mathrm{www}$.icc-cpi.int/nr/rdonlyres/ea9aeff7-5752-4f84-be940a655eb30e16/0/rome statute english.pdf> accessed 28 November 2020.

${ }^{17}$ Geneva Convention No.IV, Arts. 146 and 149.
} 
times of public emergency. ${ }^{1}$

\section{d. The Principle of Proportionality and Necessity}

The measures adopted must be strictly required by the exigencies of the situation. The GC 29 agrees that while certain right are non-derogable explicitly by the provision of Article 4(2), the measures taken to suspend the other (derogable) rights must be proportionate to the exigencies of the circumstances. ${ }^{2}$ In other words, "this condition requires that States parties provide careful justification not only for their decision to proclaim a state of emergency but also for any specific measures made pursuant to such proclamation. ${ }^{3}$ Further not only must the derogation be exigent but also the measures adopted must meet the exigency of the situation. The Committee establishes a legal obligation for states to limit all derogations to measures that are required by the exigencies of the situation. To fulfil this requirement states must state the duration, geographical coverage and material scope of the state of emergency and any measures of derogation resorted to because of the emergency. Unarguably therefore states must provide careful justification not only for their decision to proclaim a state of emergency but also for any specific measures based on such a proclamation.

e. The Principle of Consistency or Compatibility with international norms

The principle of consistency and compatibility with international norms requires that measures adopted in times of public emergency must be consistent with international norms and other obligations under international law. ${ }^{4}$ Under international human rights law states become bound by the obligations imposed by a Convention once such a state has signed; meaning that the state has approved the Convention; and then ratified; meaning that the State recognises and accepts the full legal import of its obligation under the specific treaty or convention. International human rights law admits that States can also avoid their international obligations in either of two ways. These are where a State Party has made a specific reservation to the provisions of the Convention ${ }^{5}$ and where a State Party has a valid reason for derogation of rights protected by a Convention, for example where the state declared a state of emergency, suspending certain rights or guarantees under an international Convention. ${ }^{6}$ Thus where none of these exceptions apply, states who are party to the international standards are required to put in place, measures within their domestic legislation which will not be against their obligations as set by Conventions .

$f$. The Principle of Non Discrimination

According to article 4(1) of the ICCPR, the measures adopted must not be discriminatory of any portion of the nation solely on the ground of race, colour, sex, language, religion or social origin. The UNHRCGC 29 elaborates that although article 26 and the other provisions of the ICCPR related to non-discrimination (namely articles 2, 3, 14, paragraph 1, 23, paragraph 4, 24, paragraph 1, and 25) have not been listed among the nonderogable provisions in article 4(2) of the ICCPR there are elements or dimensions of the right to nondiscrimination that cannot be derogated from in any circumstances. In particular, this provision of article 4 , paragraph 1, must be complied with if any distinctions between persons are made when resorting to measures that derogate from the Covenant. ${ }^{7}$

g. The Principle of Official Notification:

By the provisions of article 4(3) of the ICCPR state parties are obligated to give an official notification when they resort to their power of derogation. Thus a state party availing itself of the right of derogation must immediately inform the other States parties, through the United Nations Secretary-General, of the provisions it has derogated from and of the reasons for such measures. The UNHRCGC29 further explains that such notification is essential not only for the discharge of the Committee's functions, in particular in assessing whether the measures taken by the State party were strictly required by the exigencies of the situation, but also to permit other States parties to monitor compliance with the provisions of the Covenant. Further the principle of official notification extends to when the measures are expanded or extended and when the state of emergency is lifted.

\section{Terrorism as a Public Emergency in Nigeria: Applying the Standards of Article 4 of the ICCPR}

4.1. The principle of Existence of a public emergency which threatens the life of that state

Unlike the ICCPR Article 4, the Constitution of the Federal Republic of Nigeria by the provision of S. 305(3) explicates the meaning of state of emergency within the Nigeria context and states that:

The President shall have power to issue a Proclamation of a state of emergency only when- $(a)$ the Federation is at war;

\footnotetext{
${ }^{1}$ Rome Statute, Art. 7.

${ }^{2}$ UNHRC GC29 of 2001, paragraph 4.

${ }^{3}$ UNHRC GC29 of 2001, paragraph 5 .

${ }^{4}$ UNHRCGC29 of 2001, paragraph 9.

${ }^{5}$ Subject to the restriction that such reservations must not be against the objective of the Convention.

${ }^{6}$ Subject to fulfilling the conditions of Art 4 of the ICCPR

${ }^{7}$ See UNHRCGC29, paragraph 8 .
} 
(b) The Federation is in imminent danger of invasion or involvement in a state of war;

(c) There is actual breakdown of public order and public safety in the Federation or any part thereof to such extent as to require extraordinary measures to restore peace and security;

(d). there is a clear and present danger of an actual breakdown of public order and public safety in the Federation or any part thereof requiring extraordinary measures to avert such danger;

(e) There is an. occurrence or imminent danger, or the occurrence of any disaster or natural calamity, affecting the community or a section of the community in the Federation;

(f) There is any other public danger which clearly constitutes a threat to the existence of the Federation; or

$(g)$ The President receives a request to do so in accordance with the provisions of subsection (4) of this section.

\subsection{Terrorism as a Public Emergency in Nigeria}

Terrorism clashes most violently with the natural dictates of human rights principles. It defies all respect for all categories of human rights. Terrorism at all levels has been employed as instrument of wanton destructions of lives and properties. Terrorism therefore poses a great threat to the individual lives and collective well-being of a nation's life and a challenge to its fiduciary duties of protection of the life of its citizenry. Since 2009, Nigeria has been engaged in a long running battle with the Islamist sect; Jama'atu Ahlis Sunna Lidda'awati WalJihad ${ }^{l}$ nicknamed Boko Haram $(\mathrm{BH}){ }^{2}$ The acts of violence perpetrated by this so called 'Islamist' sect continue to have diverse impacts on the Nigerian nation.

The direct and indirect negative impacts of Boko Haram terrorism on the Nigerian state has been quantified in not only irreplaceable loss of human lives (human capital), but also in huge loss of properties, finance and investment. A review of reports from the Institute for Economics and Peace, publishers of the Global Terrorism Index (GTI) revealed that in 2013, for instance Boko Haram was the second deadliest terror group in the whole world. In that year alone Boko Haram was responsible for 1587 deaths of mostly defenceless non-combatant men, women and children. ${ }^{3}$ In 2014, the number of fatalities tripled to 7512 death and Boko Haram became the deadliest terrorist group in the whole world, ${ }^{4}$ an ignominious lead which it maintained in 2015 with 6644 deaths. ${ }^{5}$ The year 2016, witnessed a slight decline in the number of deaths resulting from Boko Haram terrorism with a total of 1,832 fatalities. Yet Nigeria ranked the third worst hit state in the globe. ${ }^{6}$

Even as killings committed by Boko Haram terrorism dwindled yet again in 2017, there was a resurgence in Fulani herdsmen and farmers conflicts. Nigeria maintained its mortifying third rank in the orb with 1,532 casualties resulting from both Boko Haram terrorism and Fulani herdsmen and farmers conflicts. ${ }^{7}$ The year 2018, opened into a new spike in Boko Haram terrorist activities after the lull witnessed in 2016 and 2017. With more than one hundred additional mortality than in 2017 , Nigeria ranked again as number three and was signalled as a very high impact states of terrorism by the GTI coming after Afghanistan $\left(1^{\text {st }}\right)$ and Iraq $\left(2^{\text {nd }}\right)$ with Syria the $4^{\text {th }}$ position. ${ }^{8}$ Ironically, while the morbidity impacts of terrorism lessened across the world in 2019, an increase in morbidity rate was the case in Nigeria. ${ }^{9}$ The 2020 GTI recorded an increase in the loss of lives occasioned by Boko Haram terrorists, Fulani herdsmen and kidnappers to $2,040 .{ }^{10}$

\footnotetext{
${ }^{1}$ Meaning 'People Committed to the Propagation of the Prophet's Teachings and Jihad"

${ }^{2}$ Boko Haram literally means "western education is sinful". 'Boko' in the Hausa language is a generic term associated with anything related with the West. Makaranta Boko is the Hausa equivalent for Western Education. Boko Haram. The sect protested the allegation that they are against western education and went on to clarify that they are against western civilisation and culture that is contrary to the provisions of the Glorious Quran and traditions of the Islamic faith as laid down in the ahadith. See MallamSani Umar, 'Boko Haram Resurrects, Declares Total Jihad' Vanguard Nigeria, 14 August 2009. The Boko Haram sect is a violent so called jihadist terrorist organization based in the Northeast of Nigeria with strong links with Al Qaeda. Since 2009 till date, the group has wrought substantial havoc on Nigerians and foreigners alike by its wanton destruction of lives and properties. <http://www.vanguardngr.com/2009/08/boko-haram-ressurects-declarestotal-jihad/>accessed 15 August 2020; See Christopher Bartolotta, 'Terrorism in Nigeria: The Rise of Boko Haram', (World Policy Blog, 19 September 2011) <http://www.worldpolicy.org/blog/2011/09/19/terrorism-nigeria-rise-boko-haram> accessed 10 February 2020; W. Hansen, Boko Haram: "Religious Radicalism and Insurrection in Northern Nigeria" (2015) Journal of Asian and African Studies: 1-19. DOI: $10.1177 / 0021909615615594$

3See Institute of Economics and Peace, Global Terrorism Index, 2014 Report, "Measuring and Understanding the Impact of Terrorism" $<$ http://economicsandpeace.org/wp-content/uploads/2014/11/Global-Terrorism-Index-2014.pdf> accessed 14 January 2020.

${ }^{4}$ See Institute for Economics and Peace , Global Terrorism Index,2015 Report "Measuring and Understanding the Impact of Terrorism", $<$ http://economicsandpeace.org/wp-content/uploads/2015/11/Global-Terrorism-Index-2015.pdf > accessed 14 January 2020.

See Institute for Economics and Peace, Measuring and Understanding the Impacts of Terrorism 2016, GTI

$<$ http://economicsandpeace.org/wp-content/uploads/2016/11/Global-Terrorism-Index-2016.2.pdf>accessed 14 January 2020.

6 See Institute for Economics and Peace, Measuring and Understanding the Impacts of Terrorism 2017, GTI

$<$ http://economicsandpeace.org/wp-content/uploads/2017/11/Global-Terrorism-Index-2017.2.pdf>accessed 14 January 2020.

See Institute for Economics and Peace, Measuring and Understanding the Impacts of Terrorism 2018, GTI

$<$ https://www.economicsandpeace.org/wp-content/uploads/2020/08/Global-Peace-Index-2018-2-1.pdf $>$ accessed 14 January 2020.

See Institute for Economics and Peace, Measuring and Understanding the Impacts of Terrorism 2019, GTI

$<$ https://www.economicsandpeace.org/wp-content/uploads/2020/08/GTI-2019web.pdf >accessed 14 January 2020.

${ }^{9}$ Save for Afghanistan which maintained its lead position, the rates of morbidity occasioned by terrorism fell even in Iraq and Syria.

10 See Institute for Economics and Peace, Measuring and Understanding the Impacts of Terrorism 2020, GTI https://visionofhumanity.org/wp-content/uploads/2020/11/GTI-2020-web-1.pdf accessed 2 October 2021.
} 
Terrorism definitely impacted negatively on Nigeria on many counts. First, the economic loss occasioned by terrorism and consequent loss in Foreign Direct Investment due to Boko Haram terrorism was put at US\$6.0 billion as at 2016. ${ }^{1}$ Second, the cost of countering terrorism is exorbitant. For example, Nigeria is projected to have spent about US\$9.4 billion to containment of terrorism in the year 2019, the highest in the African region. ${ }^{2}$ Third, the displacement of agrarian communities North East of Nigeria resulted into food scarcity first in that geo-political zone and then food insecurity which still plague Nigeria till date. ${ }^{3}$ Fourth and certainly not the least, the repercussions on human rights are humongous. Terrorists attacks violate the basis of all human rights, as it often targets the destruction of lives and properties.

Although Boko Haram terrorism attacks were concentrated in the North East of Nigeria and especially in Adamawa, Borno and Yobe states, the palpable negative impacts of Boko Haram terrorism reverberated all over Nigeria. Thus the direct and indirect negative impacts of Boko Haram terrorism on the Nigerian state has been quantified in not only irreplaceable loss of human lives (human capital), but also in huge loss of properties, finance and investment.

We submit that the pervasive nature of the breach and violation of human rights by acts of terrorism clearly puts terrorists' attacks in the category of circumstances which justify a declaration of state of emergency.

We submit further that the Nigerian state was justified in its construing of the situation as a state of emergency in the states under study and that the declaration of state of emergency is consistent with both national and international norms. ${ }^{4}$

\subsection{The proclamation of a state of emergency}

In the case of Landinelli Silva and Others v. Uruguay, ${ }^{5}$ the Human Rights Committee considered this situation and decided that to fulfil this requirement. A concerned state must explicate the duration, geographical coverage and material scope of the state of emergency and any measures of derogation resorted to because of the emergency. Three requirements are therefore expected to be complied with here namely: Duration of the measures, the geographical location of the states of emergency and the material scope or measures that are to be enacted and put in place by the government in the realisation of her aim of achieving normalcy.

Section 305(1) of the Constitution of the Federal Republic of Nigeria, 1999 as amended (CFRN'99) empowers the Nigerian President to declare state of emergency by means of Proclamation. In her determination to curb the menace of terrorism, on 30 January 2012, the then President Goodluck Ebele Jonathan acting under his constitutional powers declared a state of emergency for six months in some local government of four states of the North East geo-political zone, namely, Adamawa, Borno, Jigawa and Yobe states.

The Proclamation lapsed in June 2012. ${ }^{6}$ On 12 June 2012, the President established Joint Task Force for Operation Restore Order in the North East. ${ }^{7}$

The intensity and frequency of terrorists; attacks compelled the President to declare yet again state of emergency in three states namely: Adamawa, Borno and Yobe states on 20 May 2013. ${ }^{8}$ Outstandingly, however the official gazette of the Federal Government of Nigeria proclaiming the commencement of the second declaration of the state of emergency did not state the duration of the state of emergency.

This we hold is a contravention of required standard as the Committee expressed a similar concern in the case of the Syrian Arab Republic, where "Legislative Decree No. 51 of 9 March 1963 declaring a state of

\footnotetext{
${ }^{1}$ Institute for Economics and Peace, Measuring and Understanding the Impacts of Terrorism 2016, GTI <http://economicsandpeace.org/wpcontent/uploads/2016/11/Global-Terrorism-Index-2016.2.pdf $>$ accessed 14 January 2020.

2 See Institute for Economics and Peace, Measuring and Understanding the Impacts of Terrorism 2020, GTI $<$ https://visionofhumanity.org/wp-content/uploads/2020/11/GTI-2020-web-1.pdf.> p. 37, accessed 2 October 2021.

${ }^{3}$ See The United Nations Food and Agriculture Organization, Tackling food insecurity in Nigeria https://www.fao.org/resilience/newsevents/detail/en/c/1256858 accessed 11 November 2021.

${ }^{4}$ See D. Scott, 'The Systematic Failure to Interpret Article IV of the ICCPR: Is there A Public Emergency in Nigeria? American University International Law Review, Volume $15 \quad$ Issue 5, Article 5, 2000, 1164$1209<\mathrm{http}$ //digitalcommons.wcl.american.edu/cgi/viewcontent.cgi?article=1283\&context=auilr\&sei-redir=1\&referer $>$ accessed $\quad 20$ November 2020.)

${ }^{5}$ Landinelli Silva and Others v. Uruguay, Communication No. R. 8/34, J. Landinelli Silva and Others v. Uruguay (Views adopted on 8 April 1981 ) in UN doc. GAOR, A/36/40, p. 132, para. 8.3. Communication No. R. 15/64, see also C. Salgar de Montejo v. Colombia (Views adopted on 24 March 1982), UN doc. GAOR, A/37/40, Cited in 'Administration of Justice during States of Emergency' $<$ https://www.ohchr.org/Documents/Publications/training9chapter16en.pdf> accessed 15 January 2020.

${ }^{6}$ See the Constitution of the Federal Republic of Nigeria, 1999, Cap. C20, LFN 2004, S. 305;

M.T. Ladan, "Human Rights in Counter-Terrorism Environments: With Particular Reference To Nigeria" A Paper delivered at A Train The Trainer Course On Human Rights in Military Operation and Civil Military Co-operation Organized By The Office Of The National Security Adviser And EU Delegation Technical Assistance To Nigeria On CIMIC On $13^{\text {th }}-20^{\text {th }}$ October 2014.

${ }^{7}$ M.T. Ladan, "Human Rights in Counter-Terrorism Environments: With Particular Reference To Nigeria" A Paper delivered at A Train The Trainer Course On Human Rights in Military Operation And Civil Military Cooperation Organized By The Office Of The National Security Adviser And EU Delegation Technical Assistance To Nigeria On CIMIC On $13^{\text {th }}-20^{\text {th }}$ October 2014.

${ }^{8}$ See State of Emergency (Certain States of the Federation), Proclamation, 2013; Federal Government Gazette No. 27 of $20^{\text {th }}$ May 2013. (Government Notice No 84); Emergency Powers (General Regulations), 2013, Federal Government Gazette No. 28 of $20^{\text {th }}$ May 2013. (Government Notice No 85).
} 
emergency has remained in force ever since that date, placing the territory of the Syrian Arab Republic under a

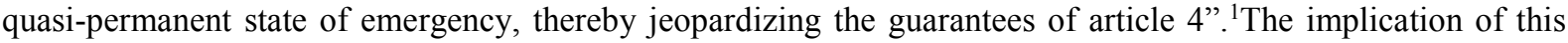
state of affair is that presently Adamawa, Borno and Yobe states are in perpetual state of emergency contrary to Article 4 of the ICCPR.

However, the geographical limits were clearly spelt out (in the Schedule to the Proclamation) as affecting three states in the $\mathrm{N}$ and worth being the area of this study, Adamawa, Borno and Yobe states and the material scope of the state of emergency are as contained in the Emergency Powers (General Regulations), 2013, Federal Government Gazette No. 28 of $20^{\text {th }}$ May 2013. (Government Notice No 85). ${ }^{2}$

We submit that the proclamation by the then President Goodluck Jonathan was legitimate it being legally guaranteed by the constitution and having proceeded from the legitimate authority who is vested with the power to invoke same. ${ }^{3}$

\subsection{The principle of Non Derogability of certain rights}

By its Constitution and other domestic laws, Nigeria guarantees respect for civil and political rights and provides for the justiciability of same. ${ }^{4}$ Nigeria by the provision of S. 45(1) however places limitations on the rights to private and family life, ${ }^{5}$ thought conscience and religion, ${ }^{6}$ freedom of expression and the press, ${ }^{7}$ peaceful assembly and association ${ }^{8}$ and the right to freedom of movement ${ }^{9}$ in the interests of the public or for the purpose of protecting the rights of others. S. 45(2) of the 1999 CFRN however enacts the derogation clause in times of public emergencies and provides thus:

An Act of the National Assembly shall not be invalidated by reason only that it provides for the taking, during periods of emergency, of measures that derogate from the provisions of section 33 or 35 of this Constitution; but no such measures shall be taken in pursuance of any such act during any period of emergency save to the extent that those measures are reasonably justifiable for the purpose of dealing with the situation that exists during that period of emergency;

Provided that nothing in this section shall authorise any derogation from the provisions of section 33 of this Constitution, except in respect of death resulting from acts of war or authorise any derogation from the provisions of section 36 (8) of this Constitution.

The provision of S.45 (2) is not explicit as to the rights which are non-derogable in times of emergencies. While the rights to life (S.33) and the right to personal liberty (S.35) were singled out as rights which may be derogated from by a valid Act of the National Assembly, the proviso to S.45 (2) recapitulates by saying that the right to life is not to be derogated from except when death occurs from acts of war. Again the proviso refers to the right to freedom from ex post facto laws and retroactive punishment (S. 36 (8)) as being non derogable.

While the intention of the drafters of the Constitution is not clear as to which rights are derogable and which are not; what is clear from a community reading of S.45 (1), S.45 (2) and proviso can be highlighted as follows:

i. Rights guaranteed under S. 37- 41 are limited in nature and are restricted even in time of peace leading to the conclusion that they are also derogable in times of public emergency.

ii. All rights guaranteed by the constitution may be derogated from in times of public emergency by a valid Act of the National Assembly.

iii. Specifically the right to life is derogable where death occurs as an act of war.

iv. Categorically, the right to personal liberty as mentioned in conjunction with the right to life may be derogated from in time of public emergency by a valid Act of the National Assembly.

v. Significantly, the right to freedom from ex post facto laws and retroactive punishment is non derogable.

From the above highlights we submit that the standard of non derogability of certain human rights as laid down by the standard setting Article 4 has not been complied with. The rights to the right to life, ${ }^{10}$ the right to human dignity, physical integrity, freedom from torture, inhuman or degrading treatment, ${ }^{11}$ freedom from slavery, ${ }^{12}$ right to freedom from retroactive punishment, ${ }^{1}$ right to equality before the law, ${ }^{2}$ right to freedom of

\footnotetext{
${ }^{1} \mathrm{UN}$ doc. GAOR, A/50/40 (vol. I), p. 69, paras. 429-430.

2 See State of Emergency (Certain States of the Federation), Proclamation, 2013; Federal Government Gazette No. 27 of $20^{\text {th }}$ May 2013.

(Government Notice No 84); Emergency Powers (General Regulations), 2013, Federal Government Gazette No. 28 of $20^{\text {th }}$ May 2013. (Government Notice No 85).

${ }^{3}$ The legality of proclamation of state of emergency in Nigeria has been canvassed in Williams v. Majekodunmi (1962) All NLR (Pt. 1) 327

at 335, Abubakar v. Attorney - General, Federation (2008) All FWLR (pt. 44) 47 at 908 paras A -C and a host of other.

${ }^{4}$ See the Constitution of the Federal Republic of Nigeria, 1999, Cap. C20, LFN 2004, S. $33-44$

${ }^{5}$ CFRN, S.37.

${ }^{6}$ CFRN, S.38.

${ }^{7}$ CFRN, S. 39

${ }^{8}$ CFRN, S.40.

${ }^{9}$ CFRN, S.41.

${ }^{10}$ ICCPR, Article 6.

${ }^{11}$ ICCPR, Art. 7.

12 ICCPR, Art. 8
} 
thought, conscience and religion ${ }^{3}$ which are expressed as non-derogable under the ICCPR are derogable under the Nigerian Constitution.

This inconsistency and blatant disregard for international norm has been the subject of concern to the Human Rights Committee and the subject of Reports and Recommendations on Nigeria issued by the Committee. First is the Committee comment and recommendation of 1 April $1996^{4}$ wherein members of the Committee expressed their total disenchantment with the state of human rights in Nigeria particularly on the spate of extra judicial killings, unlawful detentions and torture which was prevalent in Nigeria during the regime of General Sani Abacha.

A recent report and review on Nigeria by the Human Rights Committee was issued on 4 July 2019.5 Featuring a detailed interview session with the Nigerian Permanent Representative of Nigeria to the United Nations Office at Geneva, members of the Committee experts expressed concerns about the lack of respect for the international norms and the resulting overreaching and extreme applications of the Nigerian counterterrorism framework. The Committee recommended that since Nigeria had not indicated any reservations to the ICCPR it must take necessary steps to ensure her compliance with the norms enshrined therein.

We submit that not only has Nigeria refused or failed to comply with the principle of non-derogability of human rights under the ICCPR, Nigeria is also in breach of her international obligation under the African Charter on Human and Peoples' Right (hereinafter ACHPR). Interestingly, while the ACHPR allows limitation of rights (also called draw back clauses) it does not recognise derogation of any right. While a host of scholars have contended that the lack of a derogation clause in the ACHPR is a minus, ${ }^{6}$ others have argued that the noninclusion of a derogation clause in the ACHPR was a deliberate act and a right step in the right direction as it shows a positive trend in the development of human rights norms in the African region. ${ }^{7}$

Albeit, most state parties by their constitution permit derogations of rights in times of peace and in times of public emergencies. ${ }^{8}$ The jurisprudence of the African Commission on Human Rights (hereinafter African Commission) however reveals its commitment to the spirit of its tenets and have unambiguously shown that while rights may be limited, declaration of public emergency and derogation of rights consequent to same are not

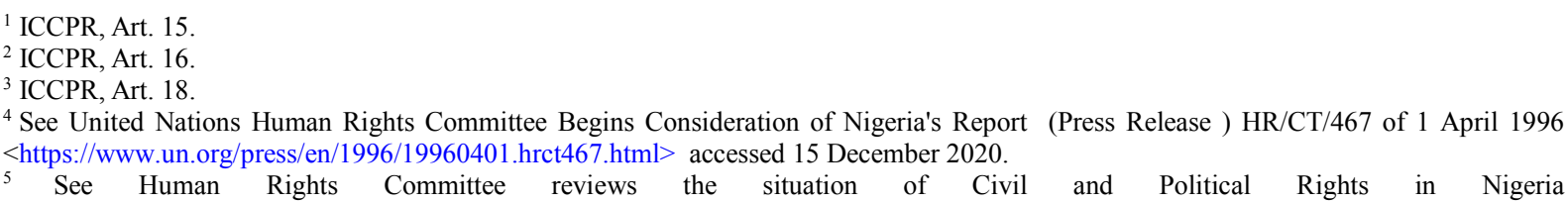
5 See Human Rights Committee reviews the situation of Civil and Political Rights
$<$ https://www.ohchr.org/en/NewsEvents/Pages/DisplayNews.aspx?NewsID=24792\&LangID=E $>$ accessed 15 December 2020.

${ }^{6}$ See Heyns C "The African regional human rights system: In need of reform?" (2001) 1 African Human Rights Law Journal155; Ouguergouz F. The African Charter on Human and Peoples' Rights: A comprehensive agenda for human dignity and sustainable development (2003); Sermet L "The absence of a derogation clause from the African Charter on Human and Peoples' Rights: A critical discussion" (2007) 7 African Human Rights Law Journal142; Murray R. The African Commission on Human and Peoples' Rights and International Law (2000); Allo A K "Derogation or limitation? Rethinking the African human rights system of derogation in light of the European system" (2009) 2 Ethiopian Journal of Legal Education. Cited by Abdi Jibril Ali “ Derogation from Constitutional rights and its Implication under the African Charter on Human and $<$ http://www.ldd.org.za/images/stories/Ready for publication/ali abdi article.pdf >accessed 15 January 2020.

7 See Abdi Jibril Ali “ Derogation from Constitutional rights and its Implication under the African Charter on Human and Peoples' Rights" $<$ http://www.ldd.org.za/images/stories/Ready for publication/ali abdi article.pdf $>$

${ }^{8}$ The Constitution of Burkina Faso, adopted on 2 June 1991, promulgated on 11 June 1991, amended on 27 January 1997 and on 11 April 2000, art 58; Constitution of the Republic of Cameroon adopted on 18 January 1996, amendment to the Constitution of 2 June 1972 , art 9; Constitution of the Central African Republic, adopted on 28 December 1994, promulgated on 14 January 1995, art 29; Constitution of the Republic of the Congo January 2002,, art 131; Constitution of the Republic of Cote d'Ivoire, adopted on 24 July 2000, art 48; Constitution of the Republic of Equatorial Guinea, adopted on 17 January 1996, Item 41; Constitution of the Gabonese Republic, adopted on 26 March 1991, amended on 22 April 1997, art 25; Fundamental Law of the Second Republic of Guinea, approved on 23 December 1990, art 74; The Constitution of the Republic of Mali, art 49; Constitution of the Fifth Republic of Niger, adopted on 18 July 1999 , promulgated on 9 August 1999, art 54 \& 86; Constitution of the Republic of Senegal, adopted on 7 January 2001, art 69; Constitution of the Fourth Republic of Togo, adopted on 27 September 1992, promulgated on 14 October 1992, art 94; Constitution of the Republic of Madagascar, adopted on 19 August 1992, amended in 1995 and 1998, art 59; Constitution of Djibouti, approved on 4 September 1992, art 62; Cited by Abdi Jibril Ali " Derogation from Constitutional rights and its Implication under the African Charter on Human and Peoples' Rights" $<$ http://www.ldd.org.za/images/stories/Ready_for_publication/ali_abdi_article.pdf > accessed on 15January 2019;Constitution of the Republic of Seychelles, approved on 18 June 1993, amended by Act No 14 of 1996, art 41. See for example, The Constitution of the People's Democratic Republic of Algeria, adopted on 19 November 1976, and amended on 28 November 1996 and on 10 April 2002 , art 91 ; Constitution of Mauritania, adopted on 12 July 1991, arts 39 \& 71. However, the 1998 Constitution of Sudan authorizes derogation from constitutional rights under art 132. ; The Constitution of the People's Democratic Republic of Algeria, adopted on 19 November 1976 , and amended on 28 November 1996 and on 10 April 2002, art 91.

Constitutional Law of the Republic of Angola, adopted on 25 August 1992, art 52; Constitutional Law of the Republic of Cape Verde, adopted on 25 September 1992, amended on 23 November 1995 and in 1999, art 26; Constitution of the Republic of Guinea-Bissau, adopted in 1984, amended in 1991, 1993, 1996, art 31; Constitution of the Republic of Mozambique, approved on 16 November 2004, art 72; Political Constitution of São Tomé and Príncipe, adopted on 5 November 1975, amended on 10 September 1990 through Law 7/90, art 18. Constitution of Mozambique, art 286. Art 52(2) of the Constitution of Angola, art 31(2) of the Constitution of Guinea-Bissau, and art 269 of the Constitution of Cape Verde contain an almost identical list of non-derogable rights. 
in conformity with the ACHPR's standard. ${ }^{1}$

We submit that Nigeria cannot hide under the provision of S. 12 of the constitution as the ACHPR is a treaty which has been transformed into Nigerian domestic law by a valid Act of the National Assembly; the African Charter on Human and People's Right (Ratification and Enforcement) Act. ${ }^{2}$

\subsection{The Principle of Proportionality and Necessity}

The Human Rights Committee has observed that the principle of strict proportionality is "a fundamental requirement for any measures derogating from the Covenant" and that it is a requirement that relates "to the duration, geographical coverage and material scope of the state of emergency and any measures of derogation resorted to because of the emergency". ${ }^{3}$

We submit that as to the material scope of the measures, the principle of proportionality and necessity has to do with the measures put in place in times of public emergencies. Crucially, the material scope of the measures are the rules regulating the conduct of state agents during public emergencies and to safeguard and prevent excesses on the parts of state agents. This principle regulates how states as fiduciary of her citizens recognise and protect human rights of her citizen by ensuring that measures put in place in times of public emergencies are designed to resolve and not escalate the conflict and are intended to return the State back to normalcy. Put in other words measures adopted under this principle must not annihilate human rights but be complementary to protection of human rights.

By a Presidential broadcast upon the proclamation of the State of Emergency, the President directed the Chief of Defence Staff to deploy more troops to the states under emergency and that such troops shall have powers to take all necessary action which may " include:

a. Imposition of Dusk to Dawn Curfew

b. Search with or without search warrants

c. Arrest and detention of suspects

d. Taking possession of any premises, buildings or structure in use by terrorists or for terrorists' purposes.

e. Lock down of areas seen as operation ${ }^{4}$

We must point out the above strategies by which it hoped to curb the menace of terrorism, were enacted into Nigerian Legal framework for combating terrorism. We submit that the above can be summed up to three of the strategies which are germane to the discourse on proportionality of Counter terrorism measures as they bear direct relevance and impact on the rights to personal dignity and personal liberty of the Nigerian residents of the area under study. The strategies are:

a. Imposition of Dusk to Dawn curfew

The imposition of the Dusk to Dawn Curfew curtails the right to personal liberty of residents of the areas in which it is declared. Be that as it we submit that to the extent which terrorism has been construed as a public emergency, the imposition of dusk to dawn curfew are reasonably justified in such state of emergency. We therefore align ourselves with the view of the Committee that the imposition of a state of emergency is an indication that law, order and indeed respect for human rights have broken down and that the situation calls for measures designed to restore normalcy such that human rights may yet again be respected. ${ }^{5}$

While it seems paradoxical to attempt to protect human rights by violating some human rights; a situation which is akin to righting a wrong with another wrong, we recall the postulations of Thomas Hobbes in his social contract theory that men submitted their rights to the states such that such rights may be collectively protected by the state. ${ }^{6}$

Further, we agree that the restriction on the freedom of movement of citizen between the dusk and dawn of each day is necessary to protect them from the marauding Boko Haram terrorists and also a way to clear the 'field' in the event of likely exchange of fire between the terrorists and the state agents. ${ }^{7}$

While we submit that the principle of necessity is satisfied by this measure, we however query its proportionality in line with allegations of mass abuse of human rights by state agents as has been revealed by the literature in terms of enforcement of this measure. There are allegations that the hours between dusk and dawn have been construed subjectively by Nigerian law enforcement and security agents. On certain days 'dusk' to

\footnotetext{
${ }^{1}$ See for example Jawara $v$ The Gambia (2000) AHRLR 107 (ACHPR 2000), Amnesty International v Zambia (2000) AHRLR 325 (ACHPR 1999), Interights and Others v Mauritania (2004) AHRLR 87 (ACHPR 2004), para 78; Prince v South Africa (2004) AHRLR 105 (ACHPR 2004); Media Rights Projects \& Ors v. Nigeria Comm. No. 224/98 (2000).

${ }^{2}$ Cap. A 10 LFN, 1990

${ }^{3}$ General Comment No. 29, in UN doc. GAOR, A/56/40 (vol. I), p. 203, para. 4.

${ }^{4}$ See Presidential Broadcast of 14 May 2013, The Guardian, Wednesday, 15 May, 2013

${ }^{5}$ General Comment No. 29, in UN doc. GAOR, A/56/40 (vol. I), 206, para. 8.

6 See Thomas Hobbes, "Leviathan", 1651, Republished by Forgotten Books, $2008<$ https//.www, forgottenbooks.org..>accessed 20 November 2020

${ }^{7}$ Human Rights Watch World Report, 2018, Section on Nigeria; 391-398. <https://www.hrw.org/sites/default/files/wr2018_web.pdf, >> accessed 20 November 2020 .
} 
state agents may mean $7 \mathrm{pm}$ while on other days may be later or earlier. There are allegations that targeted persons were sometime detained before dusk and then accused of having violated the dusk to dawn curfew thus leading to arbitrary arrest and unlawful detention of such innocent citizens. ${ }^{1}$

According to a Human Rights Watch report on Nigeria, in Damaturu, Yobe state, a military detention camp code named 'Alpha Sector' said to be housing the high risk suspects. The detention camp is also nicknamed 'Guantanamo' in deference to the notorious torture centre established by the United States Government in Guantanamo Bay, Cuba. The camp is believed to have housed not less than 1,000 of undocumented detainees who were held under untold tales of horrific, torturous and terror- laden counter terrorism strategies some of which are routinely subjected to extra judicial killings when all efforts to get incriminating evidence from them fail. $^{2}$

Amnesty International's report of 2018 disclosed that in Yola, the Adamawa state capital, the 23 Brigade Barracks housed some of the suspects of Boko Haram terrorism while a few suspects. Amnesty International estimated that between 2009 and 2017 a total of 20,000 persons must have been subjected to prolonged detention without trial at the various military detention centres. ${ }^{3}$

There are also large scale allegations of torture employed by the MJTF against terror suspects or detainees.In FRN v. Murktar Ibrahim $^{4}$ the defendant was arraigned on a five count charge of diverse terrorism offences. The defendant pleaded not guilty to all counts. At the trial, the prosecution sought to rely on four "confessional statements'; Exhibits " 6 ", "7", " 8 " and "9" allegedly made by the defendant. The defendant who testified for himself however rebutted the voluntariness of the said statements and averred that the statements were obtained from him under duress, coercion, torture and intimidation while he was in the custody of the officers of the State Security Services (SSS). ${ }^{5}$ The court found that the documents were indeed made by the defendant at "'gun point' in line with the ready made statement provided by the State Security Services officer. ${ }^{6}$ The court therefore resolved that the prosecution failed to discharge the burden of proof placed on it by S. 135 (1) of the Evidence Act and accordingly discharged and acquitted the defendants on all counts. ${ }^{7}$

We submit that the large scale allegation of torture and inhumane treatment of terror suspects as reviewed above contradict Nigeria's international obligations to protect against contracted vide the UN Convention against Torture, which Nigeria ratified on 28 June 2001. The obligation requires states to prevent acts of torture or other ill-treatment and to eliminate defences such as 'superior orders,' 'public emergency' or other any other 'exceptional circumstances' in relation to such offences. Nigeria also ratified the optional protocol to the Convention against Torture on 27 July 2009 and has also signed into law the Anti-Torture Act in July 2019. ${ }^{8}$ We do not find the proportionality of this measure as justifiable in the case of Nigeria.

b. $\quad$ Investigation by Search without Warrant

The right to personal liberty implies freedom from "external coercion in the use of one's goods or faculties. It is the status of not being the property or chattel of another." right to personal liberty to the extent that they are restricted by the provisions of S. 35(1) (a-f) and also to the extent that they are derogable under S. 45 of same Constitution which we have submitted earlier contravenes the international standards set by the ICCPR vide Article 4.

Search without warrant constitutes one of the measures enacted by the TPA which potentially violates the right of citizen to use one's self or one's goods (properties) without any external coercion. While we agree that investigation is key to tracing terrorist's movements, cells, goods and finance, the imposition of search without warrant is not a constitutional provision and does not have a place in the administration of criminal justice system in Nigeria.

As a counter-terrorism measure, search without warrant is in the spirit of the 'ticking time bomb hypothetical case'. ${ }^{10}$ The TPA provides for search without warrant where there is a verifiable urgency, or life is

\footnotetext{
${ }^{1}$ Human Rights Watch World Report, 2018, Section on Nigeria; pgs. 391-398. <https:/www.hrw.org/sites/default/files/wr2018_web.pdf, >> accessed 20 November 2020.

${ }^{2}$ Human Rights Watch World Report, 2018, Section on Nigeria; pgs. 391-398, <https://www.hrw.org/sites/default/files/wr2018_web.pdf, >> accessed 20 November 2020.

${ }^{3}$ See Amnesty International, Willingly Unable: ICC Preliminary Report and Nigeria's Failure to Address Impunity for International Crimes, Amnesty International Report of December 10 2018. <https://www.amnesty.org/en/documents/afr44/9481/2018/en/>accessed 20 November 2020.

${ }^{4}$ Unreported Judgement of Hon Justice G.O. Kolawole of the Federal High Court of Nigeria, Abuja in Charge No. FHC/ABJ/CR/178/2012 delivered on the $26^{\text {th }}$ day of November 2015. (Source: Federal Ministry of Justice, Abuja).

${ }^{5}$ Unreported Judgement of Hon Justice G.O. Kolawole of the Federal High Court of Nigeria, Abuja in Charge No. FHC/ABJ/CR/178/2012

delivered on the $26^{\text {th }}$ day of November 2015. (Source: Federal Ministry of Justice, Abuja), page 54 of judgement.

${ }^{6}$ Ibid, page 56 .

${ }^{7}$ Ibid pages $57-62$ of the judgement.

${ }^{8}$ Anti -Torture Act, 2017 assented to and signed into law by President Muhammadu Buhari on the 20 ${ }^{\text {th }}$ December 2017, available http://placng.org/wp/wp-content/uploads/2018/01/Anti-Torture-Act-2017.pdf accessed 18 January 2020.

${ }^{9}$ See the dictum of Orojo J in Oba Gabriel Orogie v. Attorney General of Ondo State 1982, 3 NCLR, 349 at 355.

10 See David Luban 'Liberalism, Torture and the Ticking Time Bomb', (2005) (91)Virginia Law Review, 1425-1461, 1437.< https://scholarship.law.georgetown.edu/cgi/viewcontent.cgi?article=1163\&context=facpub> accessed 2 March 2021;Jeremy Wisnewsky,
} 
threatened, or in acting to prevent the commission of an offence; obtaining a warrant from the court would cause delay that may be prejudicial to the maintenance of public safety or order. ${ }^{1}$ Law enforcement and security agencies are thus imbued with the power to enter any premises to search the premises or persons found in them. While the power endures we submit however that this power is subject to the limitation of necessity for reasonable suspicion and also to proportionality. Without such limitations, the power is manifestly prone to abuse and could lead to illegal, arbitrary and unlawful search of persons, premises and conveyances.

The arrest of a person upon reasonable suspicion of his having committed a criminal offence or to as may be reasonably necessary to prevent him from committing a criminal offence is justifiable and thus lawful. Arrest however becomes unlawful when it is not within the constitutional guarantee. ${ }^{2}$ By same reasoning, detention of a person for bringing him before a court in for trial (subject to bail for bail able offences) or for the execution of the sentence or order of court in respect of a criminal offence of which he has been found guilty is also lawful. It may however become lawful and thus arbitrary in nature where it is not in accordance with the law and stands null. ${ }^{3}$

Under the TPA the powers of arrest and detention are vested in the law enforcement and security agencies. Arrest may be made while conducting a search (or at other times) as any person found on any premises or place or in any conveyance may be detained by the relevant law enforcement officer of any agency until the completion of the search or investigation under the provisions of the Act. ${ }^{4}$

The Act however seems to overreach the Constitution by the provision of S. 41 whereby it empowers any law enforcement agency to obtain an ex-parte order for the detention of a suspect for a period not exceeding 90 days with subsequent renewal(s) for similar period(s) until the conclusion of the investigation and prosecution of the matter. ${ }^{5}$

We submit that this provision fosters arbitrary and unlawful detention of persons which is inconsistent with the guarantee of the right to personal liberty as enshrined in section 35 of the 1999 Constitution as amended. Specifically, S. 35(4) provides that an arrested person shall be arraigned within a reasonable time. ${ }^{6}$ Second, the constitution provides that arrested persons shall be tried within two months in the case of persons in custody and three months for a person who is on bail or be released either conditionally or unconditionally and without prejudice to further or other proceedings against him. ${ }^{7}$ Again, although it has been held by the Supreme Court that the personal liberty rights of citizens stand subdued in the interest of national security, ${ }^{8}$ it is clear that not only is the TPA inconsistent with the provision of S. 35 (4) and is thus null and void to the extent of its inconsistency, it also clashes violently with the provision of the ICCPR and the ACHPR on the inviolability of the rights to freedom from torture and inhumane treatment.

The UN Human Rights Committee has noted and commented on similar situations that the guarantees contained in article 9 (3) and (4) (the right to personal liberty) must be effectively enforced at all times, even in public emergencies threatening the life of the nation. ${ }^{9}$ This has also been found upon in several communications involving arbitrary detention of persons under what is now called euphemistically called 'administrative detention'. ${ }^{10}$

The Committee also referred to a host of other Guidelines on minimum standards of detention conditions upon which detainees may be held even in times of emergencies. ${ }^{11}$ Particularly, in Chani v. Algeria, the

'Hearing A Still Ticking time Bomb: A Reply to Bufacci and Arrigo' <https://www.academia.edu/2573114/Hearing_a_StillTicking Bomb Argument A Reply to Bufacchi and Arrigo> accessed 2 March 2021.

${ }^{1}$ S.39 as amended by substitution of Sections 24 of the 2011 Act.

${ }^{2}$ See Bobade Olutide \& Ors v. Adams Hamzat \& Ors 2016 LPELR-26047(CA)

${ }^{3}$ See Bobade Olutide \& Ors v. Adams Hamzat \& Ors 2016 LPELR-26047(CA)

${ }^{4} \mathrm{~S} .41$ (3) As amended by substitution of Section 27 of the 2011 Act.

${ }^{5}$ S. 41 (1) as amended by substitution of Section 27 of the 2011 Act.

${ }^{6}$ Interpreted to mean one day where there is a court of competent jurisdiction within a radius of forty kilometres, a period of one day; and in any other case, a period of two days or such longer period as the court may deem fit in the circumstances of the case. See the Constitution of the Federal Republic of Nigeria, S. 35(5).

${ }^{7}$ See S. 35(4) of the constitution.

${ }^{8}$ See dictum of Muhammad JSC in Dokubo -Asari v. FRN 200712 NWLR (Pt. 1048), 320 at 329.

${ }^{9}$ See GC 29, paragraph 7.

${ }^{10} \mathrm{See}$ comments/concluding observations of the Committee on Reports from Peru (1992), CCPR/C/79/Add.8, paragraph 10; Ireland (1993), CCPR/C/79/Add.21, paragraph 11; Egypt (1993), CCPR/C/79/Add.23, paragraph 7; Cameroon (1994), CCPR/C/79/Add.33, paragraph 7; Russian Federation (1995), CCPR/C/79/Add.54, paragraph 27; Zambia (1996), CCPR/C/79/Add.62, paragraph 11; Lebanon (1997), CCPR/C/79/Add.78, paragraph 10; India (1997), CCPR/C/79/Add.81, paragraph 19; Mexico (1999), CCPR/C/79/Add.109, paragraph 12. Cited in General Comment 29.

${ }^{11}$ Reference is made to reports of the Secretary-General to the Commission on Human Rights submitted pursuant to Commission resolutions 1998/29, 1996/65 and 2000/69 on minimum humanitarian standards (later: fundamental standards of humanity), E/CN.4/1999/92, E/CN.4/2000/94 and E/CN.4/2001/91, and to earlier efforts to identify fundamental rights applicable in all circumstances, for instance the Paris Minimum Standards of Human Rights Norms in a State of Emergency (International Law Association, 1984), the Siracusa Principles on the Limitation and Derogation Provisions in the International Covenant on Civil and Political Rights, the final report of Mr. Leandro Despouy, Special Rapporteur of the Sub-Commission, on human rights and states of emergency (E/CN.4/Sub.2/1997/19 and Add.1), the Guiding Principles on Internal Displacement (E/CN.4/1998/53/Add.2), the Turku (Ảbo) Declaration of Minimum Humanitarian Standards 
Committee took note of the author's allegations that he was arrested on 17 September 2009 and held incommunicado, without contact with the outside world, including counsel or his family for over seven days. The Committee held that his detention in an unknown location was not subject to the oversight of the prosecutor's office and found a violation of the author's rights to personal liberty even in times of public emergency. 1

In the European regional court of human rights, despite "the unquestionably serious problem of terrorism in South-East Turkey and the difficulties faced by the State in taking effective measures against it", a similar measure which gave power to detain persons for up to seven days was shot down by the in Aksoy v. Turkey. ${ }^{2}$

The foregoing showcases allegations of abuse of the unlawful counter terrorism measures which resulted multifarious alleged violations of the rights to personal dignity and liberty by Nigerian state agents.

We conclude that these measures cannot be justified on the ground of necessity or proportionality to the exigencies of public emergencies under international standards.

The principle of consistency of measures with other international obligations of the state is germane to ensuring that states do not hide under public emergency (as allowed by Art. 4) to breach their other international obligations be it by the norms of another treaty or by the norms of international humanitarian law or other general principles of the law so long as they relate to protection of a human rights which is affected by derogation in times of public emergencies. The Committee mandates that every State party's periodic reports must account for and present information on her other international obligations to enable the Committee to consider whether such international obligations relevant for the protection of the rights in question, in particular those obligations that are applicable in times of emergency are duly take into account of and are protected in times of public emergencies. ${ }^{3}$ In other words, no state party may hide under public emergency as allowed under Article 4 of the ICCPR to breach her international obligations under another treaty, for example under the Child's Rights Convention.

Regional courts of human rights have also pronounced on the principle of consistency and are adamant in holding that a state of emergency does not permit a derogation from rights which though are derogable under Article 4 but are non derogable under other international treaty, for example the European Convention on Human Rights. $^{4}$

We submit that Nigeria as a state party to many other treaties apart from the ICCPR, has not complied with her other international obligations as enshrined by other treaties. We have noted above that while Nigeria is a state party to the African Charter, Nigeria is in breach of her obligation as she fails to recognise the principle of non-derogability of human rights as ordained by the African Charter. We hold that Nigeria fails this test.

\subsection{The Principle of Non Discrimination}

The principle of equality and non-discrimination is the bedrock of both international human rights law and general international law. Thus any measure which seeks to derogate from the enjoyment of human rights must embed the principle of non-discrimination. Therefore any measure which discriminates between persons or groups of persons to whom the measures apply cannot stand under the provision of Article 4 and cannot be made to stand under any other treaty even when such a treaty does not expressly enshrine the non-discrimination rule. The Human Rights Committee noted that although the right to non-discrimination is not a non derogable right, it becomes enforceable however under the provision of Article 4 which mandates that measures introduced during emergency must not discriminate between persons on any basis whatsoever. ${ }^{5}$

The European Court of Human Right had cause to consider this question in the case of Ireland v. United Kingdom. The Irish government had argued that the anti-terrorism measures of arrest without warrant and administrative detention put in place in Ireland in the period of emergency between 30 March 1971 to March 1972 were targeted towards members of the Irish Republican Army (IRA) only and not directed (or if directed at all, it was to a lesser extent) to the 'Loyalist' troops who were also engaged in terrorist activities. Although the court did not find such discrimination in the circumstances of the case, it held that the requirement of nondiscrimination must be observed at all times of emergency rule. ${ }^{6}$

(1990), (E/CN.4/1995/116)

${ }^{1}$ UN HRC DECISIONS, Case No. 2297/2013 Published 7 October 2016 From 1April 2015 to 3 April 2016 and the 114th, 115th and 116th (1) of the Committee

(A/71/40https://tbinternet.ohchr.org/ layouts/15/treatybodyexternal/Download.aspx?symbolno=CCPR $\% 2 \mathrm{fC} \% 2 \mathrm{fl} 16 \% 2 \mathrm{f} 3 \& \mathrm{Lang}=\mathrm{en}$ accessed 15 January 2020.

${ }^{2}$ Eur. Court HR, Aksoy v. Turkey, judgment of 18 December 1996, Reports le 4tic1996-VI, p. 2281, para. 71, and p. 2282 , para. 77.

3 UN GC 29, paragraphs 9 and 10

${ }^{4}$ See Eur. Court HR, Lawless Case (Merits), judgment of 1 July 1961, Series A, No. 3, p. 60, paras. 40-41;Eur. Court HR, Case of Ireland v. the United Kingdom, judgment of 18 January 1978, Series A, No. 25, p. 84, para. 222; Eur. Court HR, Case of Brannigan and McBride v. the United Kingdom, judgment of 26 May 1993, Series A, No. 258-B, p. 57, para. 72.

${ }^{5} \mathrm{UN}$ doc. GAOR, A/56/40 (Vol. I), Report HRC, 204, para. 8.

${ }^{6}$ See Eur. Court HR, Case of Ireland v. the United Kingdom, Judgment of 18 January 1978, Series A, No. 25 , p. 95. 
In the case of Nigeria, none of the literature suggests that there have been any discriminatory index in the enforcement of the measures. We hold therefore that Nigeria has complied with this requirement by default means.

\subsection{The Principle of International and Official Notification:}

The principle of international or official notification is enshrined in the provision of Article 4(3) of the ICCPR which provides:

"Any State Party to the present Covenant availing itself of the right of derogation shall immediately inform the other States Parties to the present Covenant, through the intermediary of the Secretary-General of the United Nations, of the provisions from which it has derogated and of the reasons by which it was actuated. A further communication shall be made, through the same intermediary, on the date on which it terminates such derogation."

According to the Human Rights Committee, this provision is a device meant to enable the Committee assess the nature and extent of the derogation by a state and also to enable other states monitor the state's (under emergency) compliance with international standards. ${ }^{2}$ States are required under this principle to issue a communication to the United Nations Secretary General (UNSG) making full disclosure of the necessity of the emergency rule, the extent and scope of derogation as contained in the instrument of proclamation and the duration of the said measures. Communication in this regard is a two time communication which must be made at the commencement of the emergency and upon cessation of same. ${ }^{3}$ The timeliness of the communication is also of essence as the ICCP requires' immediate' notification. We submit that although Nigeria first declared a state of emergency on 30 of January 2012 and then on $20^{\text {th }}$ of May 2013, both were done without any notification to the UNSG. As at November 2019, the Nigerian state has not made the necessary communications to the UN Secretary General (UNSG) as it is required to do on why such rights have been derogated from. A visit to the UN website on communications from member states to the UNSG reveals the fact that the last communications made by the Nigerian state to the UNSG was in $2007 .{ }^{4}$

We conclude in this regard that the obligations laid down by the Art. 4(1) of the ICCPR as regards the communication to the UNSG of the declaration of the states of emergency, the reasons for and when same will abate have not been complied with by the Nigerian state.

\section{Conclusion and Recommendations}

\subsection{Conclusion}

In sum we submit that states obligation to respect, protect and fulfil human rights do not become extinct in times of public emergencies. Nigeria's obligation to respect international norms even in times of public emergency does not abate, as it must comply with certain standards of human rights protection even in times of public emergency.

Nigeria however seems to have perfected its counter terrorism strategies to counter the very lofty ideals of human rights which she is internationally obligated to protect. We submit that internationally accepted norms for derogation under international human rights law in the face of public emergency has been exceeded by the Nigerian state through draconian strategies such as arbitrary arrest, unlawful detention, extra judicial killings, inhumane treatment and torture. We submit that the general disregard for the international standards laid down for the protection of human rights continue to fan the embers of insecurity, insurgency and terrorism leading to a waning human security in Nigeria. It is imperative that Nigeria retract this trend. Our humble recommendations in this regard are laid below.

\subsection{Recommendations}

This study advocates that both the normative and institutional frameworks for countering terrorism in Nigeria needs urgent reforms to make it compliant with international standards as distilled herein.

First,we recommend the need for compliance with international best practices and the five pillars of the UN Global Counter Terrorism Strategy. Currently the implementation of NACTEST is not in compliant with international best practices and the five pillars of the UN Global Counter Terrorism Strategy. Again, there is an imperative for Nigeria to further amend her TPA to make it compliant with her grundnorm. Specifically, we prescribe the amendment of section 42 of the TPA which legitimises incommunicado detention of arrested persons as same conflicts with not only S.35 of the constitution but also violates the guarantee of the right to fair

\footnotetext{
${ }^{1}$ Similar provisions can be found in Article of the ECHR 15(3) and Article 27(3) of the ACHR.

${ }^{2} \mathrm{UN}$ doc. GAOR, A/56/40 (vol. I), p. 207, para. 17.

${ }^{3} \mathrm{UN}$ doc. GAOR, A/56/40 (vol. I), p. 207, para. 17.

${ }^{4}$ UN Human Rights Council, 'Report of the Special Rapporteur on torture and other cruel, inhuman or degrading treatment, Manfred Nowak, Mission to Nigeria' (22 November 2007) UN Doc A/HRC/7/3/Add.4 para 37 . <http://daccess-ddsny.un.org/doc/UNDOC/GEN/G07/149/66/PDF/G0714966.pdf?OpenElement> accessed 7 January 2020.
} 
hearing as enshrined under the provision of S. 36 of the constitution. ${ }^{1}$ We hold further that section 42 also constitute a breach of Nigeria's international obligations under the provisions of Article 7 of the ACHPR and Article 14 of the ICCPR. ${ }^{2}$

Second, we recommend that while the necessary amendments are made to the TPA as recommended above, the institutional framework as constituted by the Office of the National Security Adviser, (ONSA), other law enforcement and security agencies be sensitised on the need to respect and protect human rights while countering violent extremism and terrorism. Sensitisation will be achieved through programmes such as seminars, trainings and workshops for ONSA, law enforcement and security agencies.

Third, we hold that there is the need for quick dispensation of justice in the trial of terror suspects. With such prompt dispensation of justice, there would be less congestion of police and prisons custodial or detention facilities. Periodical trainings for prosecutors, forensic experts, the anti- bomb devices experts and such other expert units, officers of the ONSA other law enforcement and security agencies are also essential to eliminating the delay in trial of terror suspects often caused by unavailability of expert witnesses.

\section{References \\ Cases}

Abubakar v. Attorney - General, Federation (2008) All FWLR (pt. 44) 47.

Al-Adsani v. the United Kingdom, Application no. 35763/97, Judgment of 21 November 2001,

Amnesty International v Zambia (2000) AHRLR 325 (ACHPR 1999).

Aksoy v. Turkey, Judgment of 18 December 1996, Reports le 4tic1996-VI, p. 2281,

Bobade Olutide \& Ors v. Adams Hamzat \& Ors 2016 LPELR-26047(CA)

Brannigan and McBride v. the United Kingdom, Judgment of 26 May 1993,

Chani v. Algeria UN HRC DECISIONS, Case No. 2297/2013 Published 7 October 2016 From 1April 2015 to 3 April 2016 and the 114th, 115th and 116th sessions of the Committee (A/71/40https://tbinternet.ohchr.org/_layouts/15/treatybodyexternal/Download.aspx?symbolno=CCPR\%2f $\mathrm{C} \% 2 \mathrm{f} 116 \% 2 \mathrm{f} 3 \&$ Lang $=\mathrm{en}$

Greece v.UK, Application No157/1954-58.

Dokubo -Asari v. FRN 200712 NWLR (Pt. 1048), 320 at 329.

Interights and Others v Mauritania (2004) AHRLR 87 (ACHPR 2004).

Ireland v. the United Kingdom, judgment of 18 January 1978,

Jawara v The Gambia (2000) AHRLR 107 (ACHPR 2000).

J. Landinelli Silva and Others v. Uruguay, Communication No. R. 8/34.

Kaunda and Others v. President of the Republic of South Africa \& Others 2005 (4) SA 235 (CC);

Zimbabwe, [2008] ZWHHC 1.

Lawless v. Ireland, (Lawless Court) 3 Eur.Ct. H.R. (ser. A) (1961) (No. 3) (Court), at 56.

Mann v. Republic of Equatorial Guinea, Case No. 507/07, Judgment of 23 January 2008, High Court of Media Rights Projects \& Ors v. Nigeria Comm. No. 224/98 (2000).

Oba Gabriel Orogie v. Attorney General of Ondo State 1982, 3 NCLR, 349 at 355.

Prince v South Africa (2004) AHRLR 105 (ACHPR 2004).

Salgar de Montejo v. Colombia UN doc. GAOR, A/37/40

Williams v. Majekodunmi (1962) All NLR (Pt. 1) 327.

\section{Multilateral Conventions}

American Convention on Human Rights.

European Convention on Human Rights.

Convention Against Torture.

Convention on the Prevention and Punishment of the Crime of Genocide.

Geneva Convention Relative to the Protection of Civilian Persons in Time of War, Aug. 12, 1949, 6 U.S.T.

International Covenant on Civil and Political Rights.

Rome Statute of the International Criminal Court Geneva Convention No. IV, Arts. 146 and 149.

Vienna Convention on the Law of Treaties UNTS 18232.

United Nations'Agencies Documents: Comments and Guiding Principles

Human Rights Committee, General Comment 29, States of Emergency. Guiding Principles on Internal Displacement (E/CN.4/1998/53/Add.2),

\footnotetext{
${ }^{1}$ See S. 36 (6)(b \& c) of the Constitution.

${ }^{2}$ See Nsongurua J. Udombana, “The African Commission On Human And Peoples' Rights And The

Development of Fair Trial Norms In Africa"2006 ( 6 ) (2) AHRLJ ; 298 - 332, 303-304 <http://www.ahrlj.up.ac.za/images/ahrlj/2006 /ahrlj_vol 6 no. 22006 nsongurua j_udombana.pdf> accessed 20 November 2020.
} 
Paris Minimum Standards of Human Rights Norms in a State of Emergency

Siracusa Principles on the Limitation and Derogation Provisions in the International Covenant on Civil and Political Right.

Turku (Ảbo) Declaration of Minimum Humanitarian Standards (1990), (E/CN.4/1995/116).

\section{Foreign Statutes}

Constitution of Burkina Faso.

Constitution of the Republic of Cameroon.

Constitution of the Central African Republic.

Constitution of the Republic of the Congo.

Constitution of the Republic of Cote d'Ivoire.

Constitution of Djibouti.

Constitution of the Republic of Equatorial Guinea.

Constitution of the Gabonese Republic.

Fundamental Law of the Second Republic of Guinea.

Constitution of the Republic of Madagascar.

Constitution of the Republic of Mali.

Constitution of the Fifth Republic of Niger.

Constitution of the Republic of Senegal.

Constitution of the Fourth Republic of Togo.

Constitution of the Republic of Seychelles.

Constitution of the People's Democratic Republic of Algeria.

Constitution of Mauritania

Constitution of Sudan

Constitutional Law of the Republic of Angola,

Constitutional Law of the Republic of Cape Verde,

Constitution of the Republic of Guinea-Bissau

Constitution of the Republic of Mozambique,

Political Constitution of São Tomé and Príncipe,

Constitution of Mozambique

Constitution of Cape Verde

\section{Nigerian Statutes and Gazettes}

Anti -Torture Act, 2017State of Emergency (Certain States of the Federation), Proclamation, 2013; Federal Constitution of the Federal Republic of Nigeria, 1999, Cap. C20, LFN 2004, S. 305;

Government Gazette No. 27 of $20^{\text {th }}$ May 2013. (Government Notice No 84);

Emergency Powers (General Regulations), 2013, Federal Government Gazette No. 28 of $20^{\text {th }}$ May 2013. (Government Notice No 85).

\section{Textbooks}

Thomas Hobbes, “Leviathan”, 1651, Republished by Forgotten Books, 2008

\section{Journal Articles}

Abdi, Jibril Ali "Derogation from Constitutional rights and its Implication under the African Charter on Human and Rights.

Allo, A.K. "Derogation or limitation? Rethinking the African human rights system of derogation in light of the European system" (2009) 2 Ethiopian Journal of Legal Education.

Bartolotta Christopher, 'Terrorism in Nigeria: The Rise of Boko Haram', (World Policy Blog, 19 September $2011)<$ http://www.worldpolicy.org/blog/2011/09/19/terrorism-nigeria-rise-boko-haram>

Hansen, W. 'Boko Haram: Religious Radicalism and Insurrection in Northern Nigeria" (2015) Journal of Asian and African Studies: 1-19. DOI: 10.1177/0021909615615594.

Heyn,s C “The African regional human rights system: In need of reform?” (2001) 1 African Human Rights Law Journal, 155.

Luban, David 'Liberalism, Torture and the Ticking Time Bomb', (2005) (91)Virginia Law Review, 1425-1461, 1437.

Murray, R. The African Commission on Human and Peoples' Rights and International Law (2000)

Ouguergouz, F. The African Charter on Human and Peoples' Rights: A comprehensive agenda for human dignity and sustainable development (2003).

Scott, D. 'The Systematic Failure to Interpret Article IV of the ICCPR: Is there A Public Emergency in Nigeria? 
American University International Law Review, Volume 15 | Issue 5, Article 5, 2000, 1164-1209.

Sermet, L. "The absence of a derogation clause from the African Charter on Human and Peoples' Rights: A critical discussion" (2007) 7 African Human Rights Law Journal 142.

Udombana, Nsongurua J. 'The African Commission on Human and Peoples' Rights and The Development of Fair Trial Norms In Africa' 2006(6)(2) AHRLJ;298-332,303-304

Wisnewsky, Jeremy 'Hearing A Still Ticking time Bomb: A Reply to Bufacci and Arrigo' $<$ https://www.academia.edu/2573114/Hearing_a_Still-

Ticking_Bomb_Argument_A_Reply_to_Bufacchi_and_Arrigo>

\section{Conference Paper}

Ladan, M.T. "Human Rights in Counter-Terrorism Environments: With Particular Reference To Nigeria" A Paper delivered at A Train The Trainer Course On Human Rights in Military Operation and Civil Military Cooperation Organized By The Office Of The National Security Adviser And EU Delegation Technical Assistance To Nigeria On CIMIC On $13^{\text {th }}-20^{\text {th }}$ October 2014.

\section{Reports}

AdministrationofJusticeduringStatesofEmergency'<https://www.ohchr.org/Documents/Publications/training9cha pter16en.pdf > UN-ILC /10 GE.19-13883.

Amnesty International, "Willingly Unable: ICC Preliminary Report and Nigeria's Failure to Address Impunity for International Crimes", December 102018.

Chapter V: Peremptory norms of general international law (jus cogens), 141.

Human Rights Watch World Report, 2018, Section on Nigeria; 391-398.

Human Rights Watch World Report, 2018, Section on Nigeria; pgs. 391-398.

Human Rights Watch World Report, 2018, Section on Nigeria; pgs. 391-398.

Institute for Economics and Peace, Global Terrorism Index (GTI), Measuring and Understanding the Impacts of Terrorism, 2014.

Institute for Economics and Peace, (GTI) Measuring and Understanding the Impacts of Terrorism, 2015. Institute for Economics and Peace, (GTI) Measuring and Understanding the Impacts of Terrorism 2016. Institute for Economics and Peace, (GTI) Measuring and Understanding the Impacts of Terrorism 2017. Institute for Economics and Peace, (GTI) Measuring and Understanding the Impacts of Terrorism 2018. Institute for Economics and Peace, (GTI) Measuring and Understanding the Impacts of Terrorism 2019. Institute for Economics and Peace, (GTI) Measuring and Understanding the Impacts of Terrorism 2020. United Nations Food and Agriculture Organization,"Tackling Food Insecurity in Nigeria"., 2020 $<$ https://www.fao.org/emergencies/fao-in-action/stories/stories-detail/en/c/1256858/>

United Nations Human Rights Committee Begins Consideration of Nigeria's Report (Press Release) HR/CT/467 of 1 April 1996.

UN Human Rights Council, 'Report of the Special Rapporteur on torture and other cruel, inhuman or degrading treatment, Manfred Nowak, Mission to Nigeria’ (22 November 2007) UN Doc A/HRC/7/3/Add.4.

\section{Newspapers Reports}

Presidential Broadcast of 14 May 2013, The Guardian, Wednesday, 15 May, 2013. 